\title{
UZUAKOLI LEPER COLONY
}

T. Frank I)AVEY.

During the year 1938 the work of the Colony was maintained in all departments, but as a comprehensive report was submitted a year ago, it is proposed on this occasion chiefly to indicate the changes and new developments which have occurred during the year. Particulars are given under their respective heads.

\section{Admission and Discharge of Patients.}

There has been little change in the total population of the Colony, as I consider that a figure in the neighbourhood of a thousand is the maximum which is consistent with any real degree of personal attention. This figure had been attained at the beginning of the year, and in consequence the Colony was closed to the admission of all except a few special and needy patients for the greater part of the year.

All Native Administration quotas have been constantly full and have indeed been exceeded in two instances. The authorised total remains at 5 Io patients.

At the beginning of the year a number of so-called paying patients had reached the end of their resources and for some time they were supported by private contributions. In September the District Officer, Bende, agreed to give all lepers the right of free 
court action against their relatives if these failed to provide for them. This decision has been recommended to other Divisions. Seeing that they would be supported at home, all insolvent lepers were discharged, and during 1939 most of them will be able to receive treatment in the neighbourhood of their homes.

The admission of paying patients is almost at a standstill, but a few have been admitted and a charge of $£ 5$ has been made, this amount to cover the cost of such patients for two years.

Statistics. The following are the statistics for the year:Patients resident December 3ist, I937-

$\begin{array}{lccr}\text { Males } \ldots & \ldots & \ldots & 773 \\ \text { Females } & \ldots & \ldots & 379 \\ \text { Total } \ldots & \ldots & \ldots & \text { I I52 } \\ \text { Patients } & \text { admittell } & \ldots & 79 \\ \text { Patients } & \text { clischarged } & \ldots & \text { I I } \\ \text { Discharged cured } & \ldots & \text { I6 }\end{array}$

Discharged for other causes, including symptom free people, 95 $\begin{array}{lllll}\text { Deaths } & \ldots & \ldots & \ldots & 43\end{array}$

Number remaining on December 31st, 1938 :-

$\begin{array}{lrrrr}\text { Males } & \ldots & \ldots & \ldots & 779 \\ \text { Females } & \ldots & \ldots & 358 \\ \text { Total } & \ldots & \ldots & \ldots & \text { 1077 }\end{array}$

Use is made of the word " cured" in describing certain cases discharged, as distinct from "symptom free" . There is a reason for this. It is now common experience in Nigeria to find that there is a high relapse rate among patients discharged when all visible signs of leprosy have disappeared. There is an increasing number of symptom free people in the Colony, and before any are discharged, a probationary period of at least six months is required. At the end of this time they may be discharged as "symptom free" if they so desire.

During the year, the iodide reaction has been introduced, and patients at the end of their probationary period have been submitted to the test. By this means any latent focus of leprosy is revealed, and patients who prove nègative to the test may be considered as free from their disease, and it is therefore legitimate to use the word "cured" in their case. The number of such cases is low, but it is not anticipated that there will be relapses among them.

It is a complete fallacy to assess the usefulness of the Colony by the number of people discharged annually. If none but suitable cases were admitted it would be possible to render Ioo per cent of them symptom free. There has been a considerable change in policy at Uzuakoli during the last 18 months in regard to this matter. The Colony is not an isolated unit the sole purpose of which is to render lepers symptom free. Seeing that not more that two per cent of the lepers in the Province can be treated at Uzuakoli, and no increase in the number of such Colonies can be contemplated, it is surely the duty of the Colony to serve the 
leper population in the best possible way. For this reason, the work of the Colony is rapidly becoming specialised, and admissions are being confined to certain types of case. Ultimately, it is intended that the Colony shall consist of the following types of case only :-

I. Cases needing hospitalisation. All kinds of surgical and medical conditions arise in lepers, and at the Colony there are facilities for proper hospital treatment of all descriptions.

2. Educated lepers who can be trained for work in a scheme of leprosy control in the Province.

3. Destitute and infirm lepers whose lot involves considerable suffering and who can receive special care at the Colony.

4. Infectious cases.

5. Children, particularly those without proper guardians. These are numerous, and at the Unakoli Colony they can have careful treatment, proper diet, facilities for education and exercise, and oversight at a time when it is especially needed.

6. Sufficient strong and alsle-bodied lepers to carry out essential services, farming, etc. This must approximate to $50 \%$ of the whole.

It will be seen that when the population of the Colony is specialised in this way, statistics relating to discharges and deaths etc. offer no clue to the degree of usefulness of the Colony. As opportunity arises, new admissions to the Colony are made to conform to the new plan.

\section{Mlid)lcAl. WORK.}

The medical work of the Colony is on a tremendous scale. Every week, 2,300 leprosy treatments are given, and if dressings and the treatment of ailments other than leprosy are included, the figure approaches 4,000.

In every way, efforts are constantly made to render the medical service as efficient as possible, and for the most part there is now little to be desired.

The year has seen the introduction of a more accurate investigation of newcomers. When a patient is admitted he is now submitted to a thorough clinical and bacteriological examination, and as a routine, laboratory tests are carried out on his blood and excreta, while the Kahn test is applied to all cases.

As a result of this scientific investigation preliminary treatment is instituted which differs from one individual to another, but which meets the need of each. It is thus certain that every patient begins his specific leprosy treatment with everything possible in his favour.

Leprosy treatment is given twice weekly, intradermal injections being given on one occasion, and subcutaneous injections on the other. A variety of mixtures has been in use, and at present the experimental use of mixtures containing creosoted hydnocarpus oil without esters is being practised. Dosage is carefully regulated by the response of the patient.

The Hospital. Throughout the year the hospital has been 
full to overflowing, and with a change in the type of case admitted to the Colony, the hospital work will increase even further. During the year, numerous operations have been performed, and many types of medical case have received attention.

The Dressing Station. Early in the year, a permanent dressing station was erected in close proximity to the living quarters of the patients. This building, provided through the generosity of a friend in England, has proved a great boon to patients needing medicines and dressings who now receive treatment near their homes. At the same time congestion at the hospital has been relieved. A special staff of nurses is attached to the dressing station whose duty is to care for all weak and aged people in the Colony. An N.A. Dispenser is in charge.

Training of nurses and attendants. Considerable attention has been given to the training of leper nurses, and there is now a well trained staff of 25 nurses, many of whom are skilled at the art of giving injections for the treatment of leprosy both by the intradermal and subcutaneous routes. In the hospital nurses have received experience in the nursing of general diseases and constant teaching has been given by Mr. Lansdowne.

The development of village work has created a demand for trained attendants for out-station clinics, and a number of intelligent patients are receiving instruction in the principles of hygiene and sanitation, in the technique of leprosy treatment and in simple medicine.

Treatment centre. At present all leprosy treatment has to be given at the hospital, and the congestion which has resulted has been a serious problem. During the year, a grant was received from the British Empire Leprosy Relief Association for the building of a treatment centre. This building will be devoted to leprosy treatment and examination only, and when it comes into use early in 1939, it will place that side of the medical work on a new level.

Infectious disease. There has been very little infectious disease during the year. In October the leper chief contracted smallpox and the entire Colony was vaccinated. No further cases developed. Apart from this, and with the exception of a very occasional case of amoebic dysentery, the isolation houses remained empty throughout the year. It may be noted that the incidence of amoebic dysentery in the Colony is without doubt lower than it is in the surrounding country. During the last four months there has never been a single week when treatment for amoebic dysentery was not being given at the non-leper dispensary.

Out Patients. As reported last year, out-patient treatment at Uzuakoli had been discontinued for the following reasons :I. Adequate medical control of the out-patients was quite 
impossible. They were seen once a week, and their response to injection treatment could not be ascertained, as no record of their temperature could be obtained during the intervening days. Dosage was therefore of necessity low, and progress very slow. No case was known which had been rendered symptom free cluring $2 \frac{1}{2}$ years treatment. 2. The very fact of their having treatment was diminishing the fear of the patients in the minds of healthy people. Contacts were permitted which would have been avoided if the lepers were not having treatment. It was thus probable that out-patient treatment was actually spreading leprosy in the neighbourhood. Survey work during the later part of 1938 provided further illustrations of this sicle of out-patient treatment. In the village of Akeolu Iodu one man had so constructed his house that the only means of access to it was through the house of his father, a leper of an infectious lepromatous type. When the folly of this was pointed out to him he replied that his father had been having treatment and was therefore no longer dangerous.

During the latter part of 1938, outpatient treatment was restarted in response to hundreds of appeals from the lepers in the neighbourhood. One condition was imposed before treatment was permitted, and that was that patients receiving treatment must have segregated themselves in some way. A new outpatient department has now sprung up, in which there are 92 lepers who declare that they have fulfilled the condition. As opportunity arises they will be visited in their homes to ascertain the degree of isolation which they have imposed upon themselves. Lepers from villages which have been surveyed are also attending for the time being, pending arrangements for segregation and treatment in their own neighbourhood.

Laboratory. The laboratory has witnessed a very striking advance during the year. There are now three able non-leper workers attached to it, and most valuable work is being done. Perhaps the most important introduction has been the Kahn Test. This test has been applied to every person in the Colony. Every person admitted to the Colony is subjected to the test, and it is also used in connection with cases sent for diagnosis. No less than II99 Kahn tests have been carried out during the year. The year end has seen the introduction of the Laughlen Reaction, a simplification of the Kahn Test.

A considerable amount of bacteriological work has been done. All cases admitted are properly tested, and at intervals the examination is repeated. Before any case is discharged, at least two examinations made at an interval of six months must prove negative.

The laboratory fulfils an important need for assistance in 
diagnosis, not only in the case of leprosy but in many other diseases. Numerous examinations and tests of blood, excreta, sputum and pathological fluids have been made. The following list includes the more important tests :-

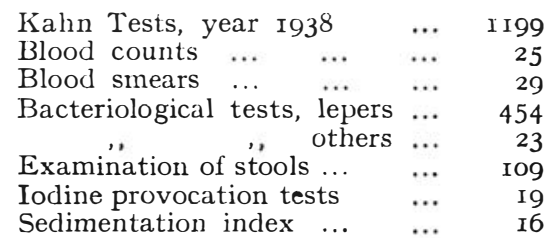

Alterations in the building have resulted in a commodious laboratory where good work is possible. A dark room has been built, and in future a photographic record of each case will be made, as this is the only scientific method of recording leprosy cases. A commencement has been made in histological work.

\section{Work Among Uninfected Childorlin.}

In last year's report it was suggested that the closing of the babies' creche may be advisable. The children are sent home, healthy and apparently strong at the age of three, and then the majority of them die (five out of seven sent home during two years).

The decision to close the creche has not been taken. In the first place it is felt that whatever may be the fate of the children when they leave the creche, its very presence is an important means of education in the prophylaxis of leprosy. It is now proposed to retain the children until they are six years of age, when they will be much better equipped to face the rigours of village life.

In itself, the creche at Uzuakoli is a model one. Children are removed from their infected mothers at birth, and are brought up on artificial foods from the start. Scrupulous care and oversight are needed, and during the year Mrs. Miller gave a considerable amount of time to this work with very great success, as there have been no deaths from marasmus or diarrhœea. The appointment of a sister is expected during 1939.

At the year end there are 14 children in our care, their ages ranging from I week to four years. The older children are not coddled. Mosquito nets are not permitted, and every effort is made to let the children develop as naturally as possible. Two small girls are employed to play with them and help them to walk and talk.

Agriculture AND INDUSTRY.

When the Colony was founded, the amount of land acquired was insufficient to support the total number of patients for whom 
the Colony was intended. Each year it has been necessary to supplement the produce obtained from the farms by a weekly subsistence allowance, the total cost of which has been in the neighbourhood of $£$ IOOO a year. During the year, negotiations have been in progress for the acquisition of new land for farming purposes. The need for this was imperative, for even with the meagre lots allowed to the patients, there is not enough land to provide a proper farming cycle, and it is necessary to rent land outside the Colony for farming purposes in 1939. Up till the end of the year no progress had been made, but at the beginning of 1939, negotiations are well in hand for the acquisition of a further 200 acres of very useful land.

There has now been a most important development in the organisation of the agricultural side of the Colony. Beginning in 1939, the active co-operation of the Agricultural Officer, Umuahia, is being obtained, and from I940 onwards, the Colony is to become a large scale demonstration of new farming methods. The whole of the farm land will be in use at one and the same time. Proper manuring is being ensured by the introduction of a small herd of cattle and the preparation of compost. A transformation in the present farming arrangements is thus hoped for, and adequate farm land will make the present scale of subsistence allowance unnecessary, and so a very useful saving will be accomplished.

During 1938 the individual system of farming was again employed with satisfactory results.

Oil Palm Plantation. This is thriving and some of the trees are bearing. For three months in the year the needs of the Colony are being met from our own trees. During 1939 a further 25 acres are being planted.

Raphia Palms. A plantation of raphia palms was commenced in 1937 in the valley around the lake, and this is in excellent condition. Coconut palms and bamboos and also sisal have been planted during the year.

Industry. The Colony is becoming more and more a selfcontained unit as far as the occupations of the people are concerned. The majority of the every-day wants of the people can now be supplied within the Colony, and every effort is made to encourage this internal industry. Carpenters provide all doors, windows, and furniture. Bedmakers, weavers, basket makers, tailors, all find scope for their skill. There are some excellent building gangs, who are becoming skilled in cement work, and these do all the building work in the Colony. The palm oil industry as has already been mentioned is growing but is not a commercial proposition at the present time. 
Social Work.

The active share played by the Methodist Missionary Society in the Colony continues, and substantial grants both by the official organisation and by private individuals have been received. A new school and a dressing station have been built out of funds given in this way.

Children. There are almost 200 children in the Colony, and scarcely a week passes but some child applies for admission because he has been more or less deserted by his relatives. A system of foster-parents exists in the Colony whereby an adult may receive a child into his house on giving an undertaking to care for that child. The subsistence allowance is then paid to him. When the children attend for treatment careful observation of their general condition is made, and if any child shows signs of neglect his guardian forfeits the right to care for him or any other child. The school has made great strides during the year. With a new building and a certificated teacher as headmaster, the teaching has been revolutionised, and the school which has 8 teachers and classes up to standard three, has now been recognised and is visited by the Education Supervisor of the Methodist Mission. Ample facilities for sport are provided for teachers and children. The football field is in constant use, while running track and ring tennis courts are available.

Arts and crafts. Native arts and crafts receive every possible encouragement. At regular intervals, competitions are held. Houses are artistically polished and decorated. At Christmas time an exhibition was held at which there were 500 entries, specimens of carving, weaving, clay modelling, pottery, Uri drawing, and painting, being submitted.

Christmas Celebrations. Christmas celebrations were on a record scale. Through the generosity of a friend, a substantial feast was provided and II head of cattle and half a ton of rice were consumed. All received gifts on December 26th, and the annual sports day on December 27 th passed off with record success, and some excellent athletic achievements.

The church continues to exercise a great influence in the Colony, promoting happiness and harmony. Contributions from the leper church people themselves have been made on behalf of destitute persons needing treatment.

The Colony and its Environment. Work In the

Surrounding Country.

The Uzuakoli Colony is situated in an area where the incidence of leprosy is probably higher than in any other part of Nigeria, 
It is scarcely an exaggeration to say that only one leper in 50 in the Owerri Province is receiving treatment at Uzuakoli, and there are few places in the world where the incidence of leprosy is higher. This is not surprising to anyone who has been actually among the people and seen how they live. A dense population, serious over-crowding in insanitary villages, houses without ventilation, in many cases a poorly balanced diet, debilitating diseases rife, these are the conditions par excellence in which leprosy spreads, and in those parts of the Bende and Okigwi Divisions with which I am familiar, they are unfortunately universal. It is difficult to find words strong enough to describe the misery of lepers in these areas. Compared with them the Colony is a veritable lepers paradise.

The leper meets with no sympathy whatever from healthy people. If he is a child he is commonly driven from the village and his fate can be imagined. If he is a strong adult he will be tolerated in the village as long as his disease is not very noticeable, especially if he is well-to-do. If, as is usual, his disease advances, toleration gives place to ostracism, and he is either forced to leave the village and live in the bush, or else he remains in the village, an object of scorn, blamed for every evil that befalls the community. Women, like children, often receive short shrift and are liable to expulsion.

There is of course considerable variation in this treatment of lepers from one village to another. On one extreme a village may be found where every leper is expelled as soon as his sickness is known to his fellows. On the other hand I have found villages where no efforts whatever are made to remove lepers, but all villages are united in the total lack of sympathy which lepers may expect. The end of the story is pitiful. Neglected by his friends, fed for a time perhaps by his companions in trouble, the leper is fortunate if some intercurrent infection supervenes and saves him from starvation.

Now I do not consider that the Uzuakoli Colony justifies its existence unless some effort is made to alleviate the condition of lepers in the surrounding country. There is only one ideal solution to the problem and that is the multiplication of Colonies such as Uzuakoli. For financial reasons that is out of the question, and the discovery of some economical but sound scheme is a very difficult if not impossible proposition. Experiment is needed, and during r938 an experimental scheme has been elaborated which is already being put into practice.

In a nutshell, the scheme consists of four consecutive phases, I Investigation, 2 Segregation, 3 Treatment, 4 Control.

I. Investigation. The first essential is to assess the size of 
the problem by means of accurate study. If anything is to be done both for the lepers themselves and also for the prevention of leprosy in the villages, all lepers must be known and the conditions obtaining in the villages must be studied. The only way by which this can be achieved is by means of thorough surveys, following the lines of approach laid down at the Cairo Conference. This entails the examination of the entire population with the taking of a census. Specially trained workers are essential, and bacteriological as well as clinical examination of both lepers and suspects is necessary. Experience is the only guide in the method of survey adopted.

2. Segregation. The only satisfactory methods of controlling leprosy which are known involve the segregation of lepers. After surveying a village, lepers are to be segregated. In some instances all lepers will be dealt with in this way, in others insistence will only be made on the segregation of bacteriologically positive cases. I am however not convinced that these are the only infectious cases, as temporary infectious phases are I believe possible in lepers who are bacteriologically negative when examined once only.

The actual method of segregation adopted will vary. In the case of a small clan with a low incidence of leprosy, good land and the possibility of oversight, a clan colony may be possible. In many instances a village colony will be preferable, while where the incidence of leprosy is high, it may be necessary to segregate lepers outside their compounds. All methods will be tried, the extent of the experiment depending upon the time and personnel available.

I am in total disagreement with the erection of large segregation centres. A community of 20 or 30 is I consider the maximum which should be permitted in the absence of resident European oversight, and it is proposed to build units of this size. Efforts are to be made to make these leper hamlets a model to the neighbourhood in village construction. As far as possible, mud block houses, proper incinerators and salga latrines will be insisted upon. The materials for building will be provided by the parent village, with the possible exception of doors and windows, etc. It is proposed to send trained leper builders from the Uzuakoli Colony to act as headmen in charge of building operations, and when the leper village is being built, a Toc H man from the Colony will plan the work and supervise the building. It may be suggested that village chiefs may not be willing to provide the assistance asked of them in the nature of materials, etc. In each case so far that has not been the case, chiefs being eager to assist when lepers are to be removed from 
the community. If such a case did arise, leprosy relief work would be stopped altogether in that village until such time as the chiefs had acquired a little wisdom.

3. Treatment. Every effort must be made to overcome the hopeless outlook of the lepers themselves. This will in part be achieved by new conditions of living, but it is considered that treatment should be given, not only for leprosy itself, but for ulcers, etc. For this purpose a chain of leprosy clinics will be instituted. These will be built of the cheapest materials, permanent buildings being most undesirable, as they may have to be moved to another site if the scheme passes out of the experimental stage and becomes general. Visits will be paid to these clinics every week by a responsible person from Uzuakoli, either the doctor or a Toc $\mathrm{H}$ man, and leprosy treatment will be given to the lepers who are segregated in the area. Associated with each clinic there will be an attendant, himself a leper, who has been trained at Uzuakoli, and he will actually give the injections. It is proposed to receive into training lepers who will work in the neighbourhood of their own homes, who will not only give injections at the local clinic, but who will be able to dress ulcers, attend to minor ailments, and visit the leper hamlets to ensure their cleanliness.

From what has been said under the head of " Out-patients," It will be seen that I have but little faith in injections per se as a means of leprosy control. It is a part, but not a fundamental part of the scheme, more insistence being given to the segregation of infectious cases.

4. Control. In its further working out the scheme will be concerned with the villages from which lepers will have been segregated. With segregation accomplished, the Leprosy Ordinance must be invoked. A proper census having been taken, all contacts will be known and will be examined periodically. Finally, at intervals of 2 years the village will be resurveyed, and in this way the success or otherwise of the scheme will be determined.

Considerations in Managing the Scheme.

I. Support of segregated lepers. It may be stated that if we segregate lepers we make ourselves responsible for their upkeep if by segregation we have disturbed their means of livelihood. It is proposed that in no case will lepers be segregated more than one or at most two miles from their former homes. Able bodied lepers will thus be able to continue their former means of livelihood. With regard to feeble lepers, these at present die miserably. A local arrangement has been made in the Bende 
Division whereby all lepers unable to support themselves are made chargeable to their relatives. This is quite reasonable, is in line with the Ibo idea of family responsibility, and should be made a definite law, applying to other Divisons as well. If properly applied, this arrangement considerably simplifies the question of the support of feeble lepers. It will to be seen whether it is satisfactory in practice.

2. Children of Lepers. It may be objected that segregation will probably increase the number of children born to lepers. I very much doubt this. At present the husbands of leper wives usually lose interest in them, even if they are not driven from home, and if they are going to have children, children will be born whether the women are segregated or not.

Children born in leper hamlets will remain with their mothers until they are at the weaning age. To remove them earlier is to take them to certain death. If at the age of two years a child shows no signs of leprosy, he may be brought back to the parent village, provided that during those two years no suspicious signs have occurred, and also provided that his presence in the parent village is permitted only if he is examined at regular and frequent intervals. If this cannot be assured he should stay in the leper hamlet. This means that he will probably contract leprosy, but however unpleasant that may be, the alternatives are even worse. It is clear from these considerations that leprosy will not be eradicated in one generation, but that it is a case of accepting the better of two very undesirable alternatives.

3. Co-operation of Government Departments. The active co-operation of Government Departments is vital to the scheme. We have already found that although there is a general willingness to co-operate in segregation on the part of the people, there is very little desire for lepers to receive treatment. Provided the leper is removed, his further welfare is immaterial. There has already been active opposition to the building of clinics, and in matters such as this, the co-operation of the Administration is vital. With regard to the building of leper hamlets, the co-operation of the Health Authorities is desirable with respect to the site, and again the Administrative Authorities can assist with the question of land tenure and ownership. Sanitary inspectors should receive special training in the diagnosis of leprosy, as it will fall to their lot to examine contacts and any children in the parent village who have been exposed to infection.

4. Financial Considerations. From a financial point of view the scheme is most economical. There are five heads under which expenditure is incurred. 
(a) Salaries of trained non-leper surveyors and laboratory workers. This is not high and is relatively constant.

(b) Transport costs. This is the largest item, and will vary with the amount of work done.

(c) Salaries of leper clinic attendants. These will be low, in the neighbourhood of $£ 6-£ 9$ per annum for each man.

(d) Cost of drugs and dressings. The specific leprosy drugs (hydnocarpus oil, etc.) are supplied free of charge, but at every clinic there attend cases of leprosy with urgent needs for other treatment, particularly in the matter of dressings for ulcers, and treatment for these is inevitable if we are to be of material assistance to the lepers. With the extremely limited financial support available, it will be necessary to exercise the utmost economy. We have estimated for an expenditure of $£$ Io under this head for 1939 .

(e) Cost of building materials. Where it is necessary, windows, doors, etc. will be made at the Uzuakoli Colony, and thus the cost of materials alone will be required. The amount spent under this head will be low.

It must again be reiterated that the scheme is experimental, that it is far from the ideal, but I believe that it offers the best hope of facing the problem with the resources that are available, and is in line with well informed medical opinion concerning the control of the disease.

5. Relation of the Uzuakoli Colony to the scheme. It will be seen that the Uzuakoli Colony bears a vital relationship to the scheme, for it is the centre from which the scheme will be directed. Non-leper workers are trained here. Leper clinic attendants are already receiving instruction. Leper builders will be sent to leper hamlets.

Reference has already been made to the types of case for whom the Uzuakoli Colony will cater in the future. They may be enumerated again as follows :-

(a) Destitute lepers without relatives.

(b) Lepers needing hospitalisation.

(c) Infectious lepers.

(d) Educated lepers who may be trained for village work, nurses, etc.

(e) Children, who can receive special oversight.

(f) Sufficient able-bodied lepers to manage the work of the Colony.

The functions of the Colony will be :-

I. Appropriate care for those types of case segregated there.

2. Hospital work, surgical and medical. 
3. Training of leper workers, nurses.

4. Research. In this connection it must be noted that the village scheme is futile unless accurate records are kept and all examinations are thorough. A special record room has been reserved at the Colony.

5. Education. By demonstrating the best methods of treatment known, by the babies creche, and in many other ways, it is hoped that education concerning the disease can be disseminated. Courses of study for sanitary inspectors in training are already being arranged, and instruction in schools in the neighbourhood has already been given.

\section{The Progrless of the Scheme.}

On the return of the Medical Superintendent from leave, letters were addressed to all the clan councils in the Bende Division, and also to one or two in the Okigwi Division. The Councils were asked to state their attitude to surveys, segregation, and clinics, and within a short time, replies had been received from $I_{5}$ out of $\mathrm{I} 7$ clans in the Bende Division. Visits were then made to most of these, and the full details of the scheme were expounded. In every case great eagerness was shown for the early start of this work, and full co-operation was promised. The following is the present position.

Nkporo. A survey was carried out last year. The people already segregate the majority of their lepers in villages which are appallingly bad. A clinic has been opened with 200 patients from the immediate neighbourhood, and a leper village is to be built immediately on the lines already laid down.

Alayi. A clinic was started but was wrecked by a near-by village the people of which objected to lepers having treatment at the site selected. The chiefs have found a new site and the clinic has been reopened.

Ohuhu Clan. A survey is in progress, after which a clinic is to be erected and segregation arranged.

Umuimenyn Clan. The village of Akaelu Lodu has been surveyed. At present the lepers are attending at the Uzuakoli Colony for treatment, but segregation will be achieved during this year. Other surveys are pending in this clan.

Oboro Clan. A survey has been arranged, to take place in March. A clinic and leper village will follow.

Ibeku Clan. A survey has been requested and a site for a leper village offered. The same is true of the Ozuitem Clan.

Igbere Clan. A leper village was visited in the Igbere area and was the worst I have seen. A clinic is to be started and new villages built after survey. 
During the coming year it is hoped to open clinics at Ovim and also at Umuduru.

The survey of all these areas will take a considerable time, and they probably represent the maximum that can be achieved with present staff and financial resources.

Acknowledgments.

I have to acknowledge with thanks the following :I. A grant of $£ 50$ from B.E.L.R.A., Nigerian Branch.

2. A grant for a treatment centre from B.E.L.R.A., Head Office. 3. Numerous gifts from interested people in England, the majority of whom are associated with the Methodist Church.

My grateful thanks are also due to Toc $\mathrm{H}$ colleagues for unstinting service during the year, to Dr. D'Amien and to Dr. Miller, who acted as relief, and also to Mrs. Miller for her assistance in the babies creche. 